\title{
IDENTIFIKASI SUARA MENGGUNAKAN METODE MEL FREQUENCY CEPSTRUM COEFFICIENTS (MFCC) DAN JARINGAN SYARAF TIRUAN BACKPROPAGATION
}

\author{
Voice Identification Using Mel Frequency Cepstrum Coefficients (MPCC) and Back- \\ Propagation Artificial Neural Network Technique \\ Erina Nursholihatun ${ }^{1}$, Sudi Mariyanto Al Sasongko ${ }^{1}$, . Abdullah Zainuddin ${ }^{1}$ \\ 1) Jurusan Teknik Elektro, Fakultas Teknik, Universitas Mataram, Nusa Tenggara Barat, Indonesia \\ Email : erinanurholihatun06@gmail.com; mariyantosas@unram.ac.id; Abdullahzainuddin@yahoo.com
}

\section{ABSTRAK}

Suara merupakan alat komunikasi paling dasar yang digunakan manusia. Pengenal penutur merupakan proses mengenali identitas dari seorang penutur dengan membandingkan fitur-fitur suara yang dimasukkan dengan semua fitur-fitur dari setiap penutur yang ada dalam database. Proses identifikasi penutur terdiri dari dua tahap yaitu tahap pengekstrakkan ciri dan tahap pengenalan pola. Tahap pengekstrakan ciri digunakan metode mel frequency cepstrum coefficient (MFCC). Pada tahap pengenalan pola digunakan metode jaringan syaraf tiruan backpropagation dengan cara membandingkan antara data uji dengan data referensi pada database berdasarkan variabel hasil proses pembelajaran.

Hasil penelitian membuktikan bahwa peningkatan level SNR (Signal to Noise Ratio) akan menentukan keberhasilan sistem pengenalan penutur. Semakin tinggi level SNR maka persentase pengenalannya akan meningkat. Tingkat pengenalan penutur pada data suara tanpa noise menghasilkan nilai akurasi rata-rata sebesar $86 \%$, data suara dengan akurasi pengenalan terbesar terdapat pada SNR $80 \mathrm{~dB}$ sebesar 92\% dan akurasi pengenalan terendah yaitu sinyal dengan SNR 20 dB sebesar $45 \%$. Sedangkan untuk pengujian penutur diluar database diperoleh hasil tingkat penolakan sebesar 100\%.

Kata Kunci : MFCC, Jaringan Syaraf Tiruan Backpropagation, Pengenalan Penutur, SNR (Signal to Noise Ratio)

\section{ABSTRACT}

The voice is basic humans tool of communications. Speakers identifications is the process of recoqnizing the identity of a speaker by comparing the inputed voice features with all the features of each speaker in the database.There are two step of speaker identification process: feature extraction and pattern recognition. For the characteristic extraction phase using $\mathrm{Mel}$ Frequency Cepstrum Coefficient (MFCC) method. The method of pattern recognition using backpropagation artificial neural networks that compares the test data with the reference data in the database based on the variable result in the learning process.

The result from the research show that increasing SNR (Signal to Noise Ratio) value will determine the success of the speaker recognition system. The higher SNR (Signal to Noise Ratio), will increase percentage level of recognition. Average accuracy speakers recoqnition of the speakers data without noise generating is $86 \%$, the biggest average accuracy speakers recoqnition is $92 \%$ in the data with $80 \mathrm{~dB}$ SNR level, and the lowest average accuracy is $45 \%$ in the data with $80 \mathrm{~dB} S N R$ level. Rejection rate testing result of speakers outside the database is $100 \%$.

Keywords: MFCC, Artificial Neural Networks Backpropagation, Speaker Identification, SNR (Signal to Noise Ratio)

\section{PENDAHULUAN}

Suara merupakan alat komunikasi paling dasar yang digunakan oleh manusia. Perkembangan teknologi memungkinkan manusia tidak hanya berinteraksi dengan manusia saja, tetapi seringkali juga harus berinteraksi dengan perangkat-perangkat teknologi seperti komputer. Komputer tidak dapat mengerti bahasa yang penutur ucapkan, sehingga diperlukan sebuah sistem pengenalan penutur (speaker identification).

Pengenal penutur merupakan proses mengenali identitas dari seorang penutur dengan membandingkan fitur-fitur suara yang 
dimasukkan dengan semua fitur-fitur dari

Penelitian ini merancang dan menganalisis simulasi identifikasi penutur. Sistem akan mengidentifikasi (mengenal) suara penutur dari 18 orang penutur yang terdiri dari 18 suara pria dengan umur rata-rata 22-24 tahun dengan menggunakan perangkat lunak Matlab.

Pada sistem pengenalan suara oleh manusia terdapat tiga organ penting yang saling berhubungan yaitu telinga yang berperan sebagai transduser dengan menerima sinyal masukan suara dan mengubahnya menjadi sinyal syaraf, jaringan syaraf yang berfungsi mentransmisikan sinyal ke otak, dan otak yang akan mengklasifikasi dan mengidentifikasi informasi yang terkandung dalam sinyal masukan.

Proses produksi suara pada manusia dapat dibagi menjadi tiga yaitu:

1. fisiologis: pembentukan aliran udara dari paru-paru

2. phonation: perubahan aliran udara dari paru-paru menjadi suara, baik voiced maupun unvoiced

3. artikulasi yaitu proses modulasi/ pengaturan suara menjadi bunyi yang spesifik.

Organ pembentuk sinyal suara meliputi:

1 Bagian pulmonary tract: terdiri dari paruparu dan batang tenggorokan

2 Bagian larynk: terdiri dari tali-tali vocal. Ruang antara pita suara disebut glottis

3 Bagian vocal tract: terdiri dari pharyng, rongga mulut, dan rongga hidung, seperti dapat dilihat pada gambar 1 .

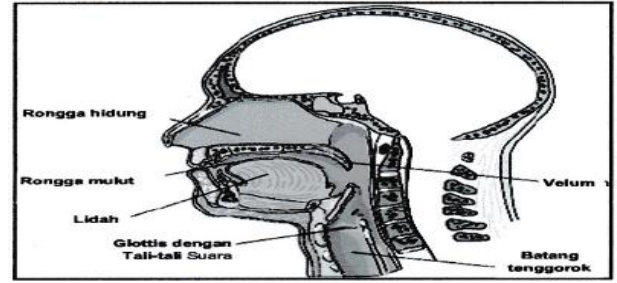

Gambar 1. Organ-organ produksi suara

\section{Metode Mel Frequensy Cepstrum Coefficient}

Feature extraction (ekstraksi ciri) merupakan proses untuk menentukan satu nilai atau vektor yang dapat dipergunakan sebagai penciri obyek atau individu. Dalam pemrosesan suara, ciri yang biasa dipergunakan adalah mel frequency cepstrum coefficients (MFCC) yang menghitung koefisien cepstrum dengan mempertimbangkan persepsi sistem setiap penutur yang ada dalam database.

pendengaran manusia terhadap frekuensi suara. MFCC didasarkan pada variasi yang telah diketahui dari jangkauan kritis telinga manusia dengan frekuensi. MFCC memiliki 2 jenis filter dimana bersifat linear pada frekuensi dibawah $1000 \mathrm{~Hz}$ dan bersifat logaritmic pada frekuensi diatas $1000 \mathrm{~Hz}$. Beberapa keunggulan dari metode ini adalah :

a. Mampu untuk menangkap karakteristik suara yang sangat penting bagi pengenalan suara, atau dengan kata lain dapat menangkap informasi-informasi penting yang terkandung dalam sinyal suara.

b. Menghasilkan data seminimal mungkin, tanpa menghilangkan informasi-informasi penting yang dikandungnya.

c. Mereplikasi organ pendengaran manusia dalam melakukan persepsi terhadap signal suara [1].

Blok diagram pemrosesan mel frequency cepstrum coefficients (MFCC) dapat dilihat pada gambar 2:

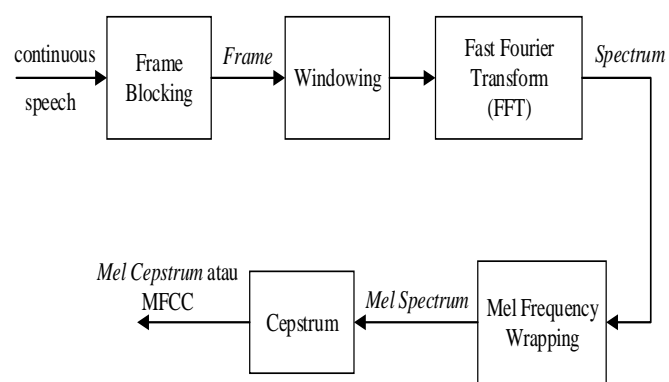

Gambar 2. Blok diagram mel frequency cepstrum coefficients (MFCC) [2].

\section{Jaringan Syaraf Tiruan}

Jaringan syaraf tiruan (JST) adalah suatu sistem pemrosesan informasi yang mempunyai karakteristik menyerupai jaringan syaraf manusia.

Komponen penyusun jaringan syaraf tiruan seperti gambar 3 .

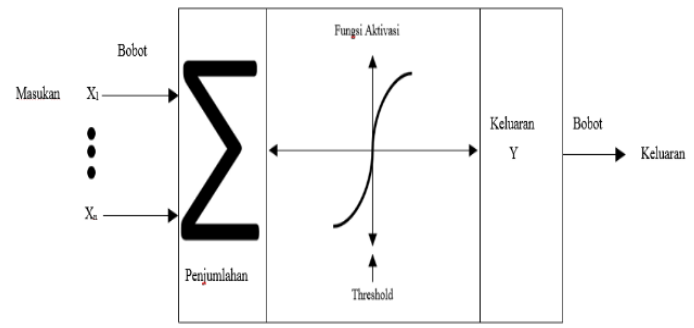

Gambar 3. Komponen Jaringan Syaraf Tiruan [3]. 
Keterangan gambar komponen penyusun jaringan syaraf tiruan adalah:

- $X_{1}, X_{2}, X_{3}, X_{n}$ adalah sinyal yang masuk ke sel syaraf

- $W_{1}, W_{2}, W_{3}, W n$ weight (bobot): factor bobot penghubung antar node

- Setiap input akan dikalikan dengan bobot dari node-nya masing-masing, $X^{T} W$. Tergantung dari fungsi aktivasi yang dipakai, nilai $X^{\top} W$ dapat membangkitkan (excite) node atau menghalangi (inhibit) node

- Nilai ambang internal (Threshold) dari node

- besarnya offset yang mempengaruhi aktivasi pada output node $Y$

$$
Y=\sum_{i=1}^{n} X_{i} W_{i}-\emptyset
$$

- Fungsi aktivasi: operasi matematik yang dikenakan pada sinyal output Y. Ada beberapa fungsi aktivasi yang biasa dipakai dalam JST tergantung masalah yang akan diselesaikan.

\section{Fungsi Aktivasi}

- Fungsi sigmoid biner yang mempunyai rentang nilai $(0-1)$

$$
f_{1}(x)=\frac{1}{1+\exp (-x)}
$$

$$
\text { dengan } f_{1}{ }^{\prime}(x)=f_{1}(x)\left[1-f_{1}(x)\right]
$$

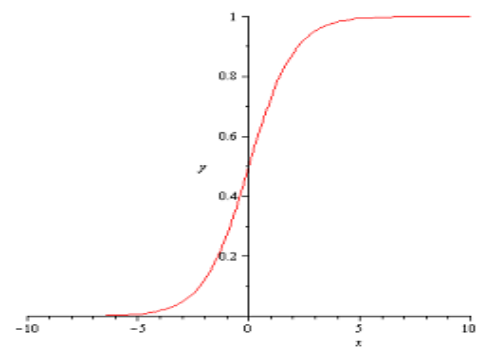

Gambar 4. Fungsi sigmoid biner [4]

Fungsi sigmoid bipolar dengan rentang (1,1)

$$
f_{2}(x)=-1
$$

dengan $f_{2}^{\prime}(x)=1 / 2\left[1+f_{2}(x)\right]\left[1-f_{2}(x)\right]$

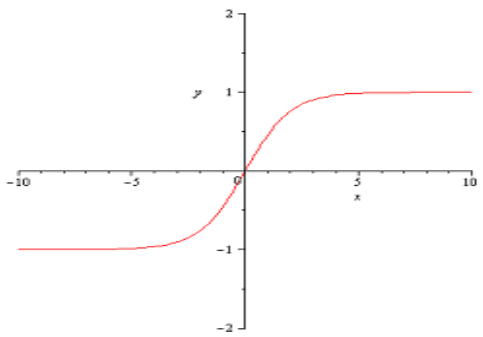

Gambar 5. Fungsi sigmoid bipolar [4].

Backpropagation adalah salah satu arsitektur JST yang paling luas digunakan dan telah berhasil diaplikasikan dalam berbagai bidang. Jaringan syaraf tiruan backpropagation terdiri dari beberapa lapisan (layer) yaitu:

- Lapisan input (input layer): berfungsi mempresentasikan data kedalam JST untuk diproses

- Lapisan tersembunyi (hidden layer): neuron didalamnya disebut unit tersembunyi, yang tidak dapat diobservasi langsung dan tersembunyi. Lapisan ini menyediakan fungsi nonlinieritas pada JST.

- Lapisan output (output layer): berfungsi mengkodekan output JST ke suatu informasi yang dapat dimengerti [5].

\section{METODE PENELITIAN}

Metode yang digunakan dalam penelitian ini adalah pertama pengambilan sampel penutur yang terdiri dari suara laki - laki dan perempuan yang berumur rata-rata $22-24$ tahun, masing-masing penutur mengucapkan satu pola kata yang sama yaitu kata "Laboratorium Telkom". Kedua adalah memproses MFCC untuk mendapatkan ekstraksi ciri dari masing-masing penutur. Ketiga adalah proses pelatihan, pada proses ini pola kata yang sudah ditentukan dimasukkan secara urut mulai penutur 1 , penutur 2 seterusnya sampai penutur terakhir. Keempat adalah menguji penutur dengan MFCC dan jaringan syaraf tiruan backpropagation untuk mengenali penutur. Kelima yaitu menganalisa dan pengambilan kesimpulan.

Dalam proses perancangan suatu sistem dilakukan penelitian dan penganalisaan tentang sistem yang akan dibangun, gambar 6 adalah diagram alur penelitian pengenalan penutur (speaker identification). 


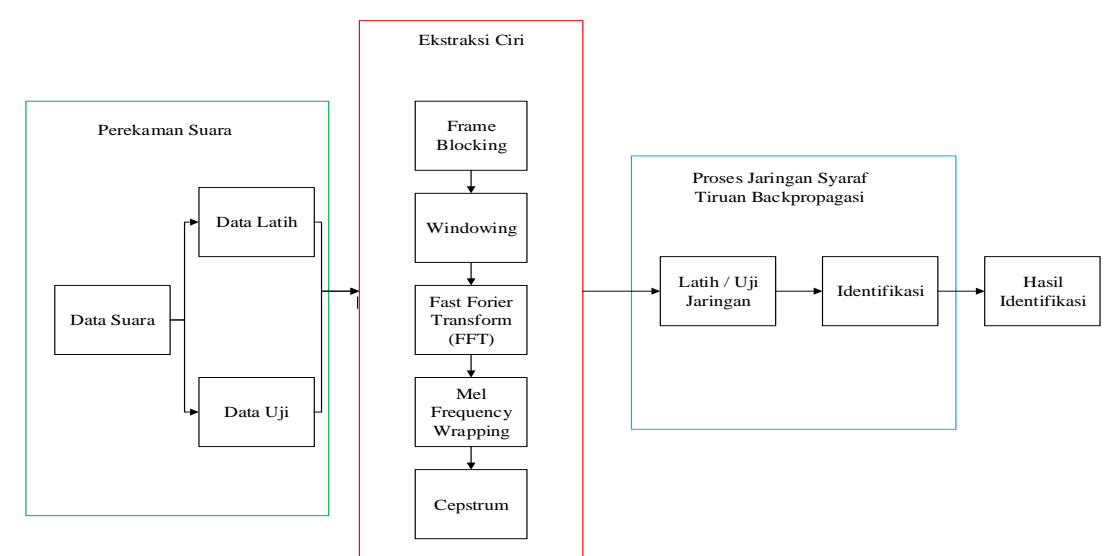

Gambar 6. Diagram alur penelitian identifikasi penutur

Perekaman suara digunakan sebagai masukan perintah dilakukan dengan menggunakan program software Goldwave. Gambar 7 menunjukan proses perekaman suara.

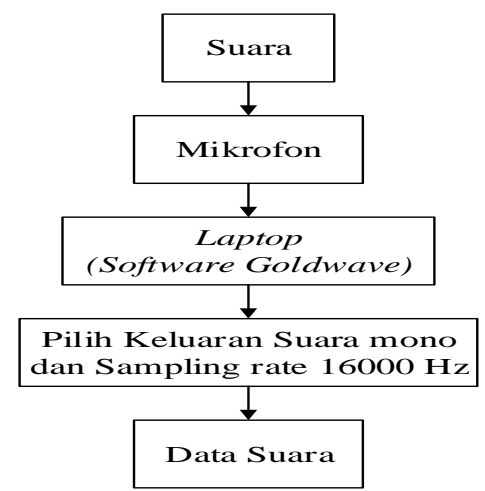

Gambar 7. Diagram alir proses perekaman suara

Data yang berupa sinyal suara penutur direkam dengan menggunakan mikrofon yang terhubung dengan laptop. Perekaman suara dilakukan dengan bantuan program GoldWave, dengan frekuensi sampling 16000 $\mathrm{Hz}, 16$ bit, mono channel. Kemudian suara tersebut disimpan dalam bentuk file yang bereksitensi ".wav".

Perekaman dilakukan sebanyak 13 kali ucapan untuk data dalam database. Dimana 3 dari 13 data hasil perekaman digunakan sebagai data latih dan pengujian. Sedangkan 10 lainnya hanya digunakan sebagai data uji. Untuk data diluar database dilakukan perekaman suara sebanyak 5 kali ucapan. Dimana hasil perekaman data diluar database digunakan sebagai data uji pada sistem JST. Hasil dari perekaman kemudian disimpan dalam bentuk format .wav.

Ekstraksi ciri sinyal suara pada penelitian ini menggunakan MFCC. Parameter dari MFCC yaitu : a.

nput, yaitu masukan suara yang berasal dari tiap pembicara.

b.

ampling rate, yaitu banyaknya nilai yang diambil dalam satu detik. Dalam penelitian ini digunakan sampling rate sebesar 16000 $\mathrm{Hz}$.

c.

ime frame, yaitu waktu yang diinginkan untuk satu frame (dalam milidetik). Time frame yang digunakan adalah $50 \mathrm{~ms}$.

d.

ap, yaitu overlaping yang terdiri dari $\mathrm{N} / 2$ data.

e.

epstrum coefficient, yaitu jumlah cepstrum yang diinginkan sebagai output. Cepstrum coefficient yang digunakan sebanyak 13. Batasan jumlah koefisien sebanyak 13 didapat dari nilai spectrum frekuensi data suara yang dominan.

Tahapan proses MFCC dapat diilustrasikan sebagai berikut:

\section{Frame Blocking.}

Hasil perekaman suara merupakan sinyal analog yang berada dalam domain waktu yang bersifat variant time. Oleh karena itu sinyal tersebut harus dipotong-potong dalam slot-slot waktu tertentu agar dapat dianggap invariant. Dalam penelitian ini digunakan frekuensi sampling $16000 \mathrm{~Hz}$ dan sinyal suara dipotong sepanjang 50 milidetik. Dimana perhitungannya adalah sebagai berikut:

Sampling rate $(\mathrm{Fs})=16000 \mathrm{~Hz}$

Timeframe $(\mathrm{Ts})=50 \mathrm{~ms}$ atau $0,05 \mathrm{~s}$

Frame size $(\mathrm{N})=16000 * 0,05=800$ sample

Overlaping $(\mathrm{M})=800 / 2=400$ sample. 


\section{Hamming Window.}

Hamming Window diperlukan untuk mengurangi efek diskontinuitas dari proses frame blocking terutama pada ujung awal dan ujung akhir setiap frame.

\section{Fast Fourier Transform.}

Dalam proses fourier transform akan mengubah sinyal suara dari domain waktu ke dalam domain frekuensi.

\section{Mel Frequency Wrapping.}

Mel frequency wrapping bertujuan untuk proses pemfilteran dari spektrum setiap frame.

\section{Cepstrum.}

Cepstrum merupakan hasil logaritme mel spectrum dari domain frekuensi yang dirubah menjadi domain waktu dengan menggunakan DCT dimana menghasilkan matriks yang berukuran jumlah frame * koefisien.

Sebelum melakukan proses pelatihan jaringan syaraf tiruan backpropagation terlebih dahulu diperhatikan arsitektur jaringan. Tiap neuron pada lapisan masukan terdiri dari hasil ekstraksi ciri dengan metode MFCC dan meneruskannya ke neuron pada hidden layer diatasnya

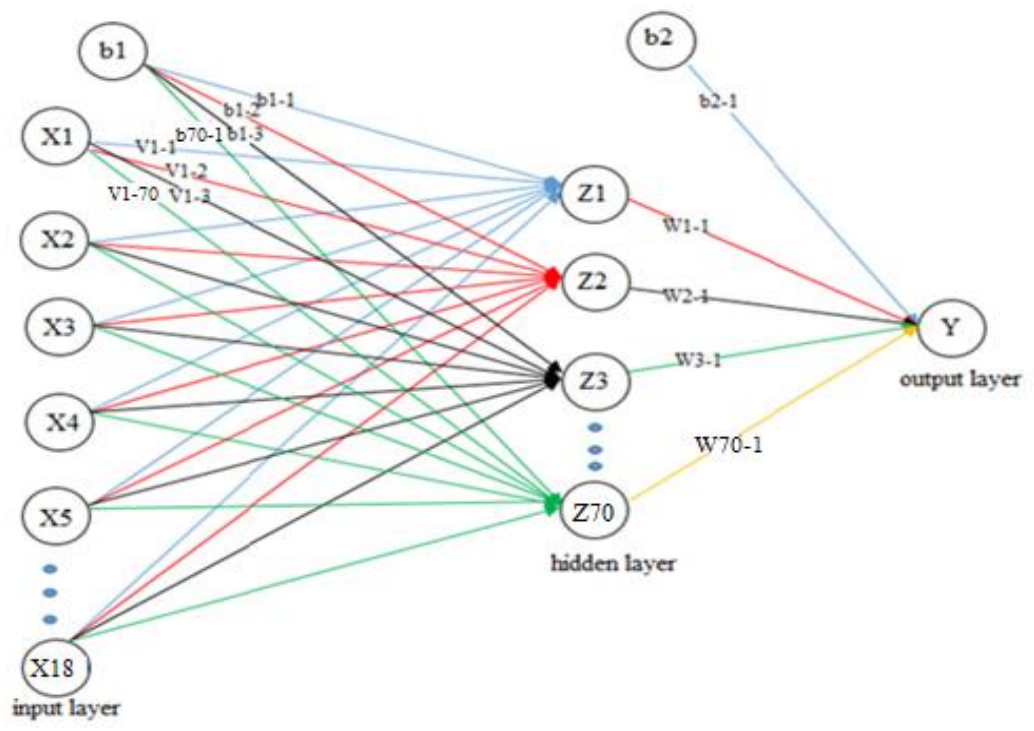

Gambar 8 Arsitektur JST untuk pengenalan penutur

Skema proses latih jaringan dapat dilihat pada gambar 9.

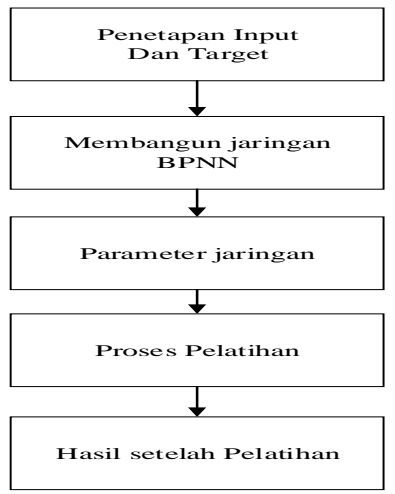

Gambar 9 Skema proses latih jaringan a. Input Data

Nilai data input adalah bebas artinya nilai dapat diisi dengan sembarangan bilangan berdasarkan data yang diperoleh pada penelitian. Data tersebut kemudian disusun dalam bentuk matriks dengan ukuran matriks $39 \times 18$ untuk data yang akan digunakan sebagai data pelatihan.

b. Membangun JST Backpropagation

c. Parameter jaringan Inisialisasi parameter pelatihan yang meliputi laju pembelajaran, momentum, goal, serta jumlah iterasi.

d. Pelatihan JST Backpropagation Setelah membangun JST Backpropagation dan menentukan parameter jaringan langkah komputasi selanjutnya adalah melakukan proses pelatihan JST. 
- Pelatihan 1, Mencari Jumlah Neuron untuk Hidden Layer. Tujuan dari langkah ini adalah menentukan jumlah neuron untuk hidden layer yang menghasilkan kinerja terbaik selama proses pelatihan, ditunjukkan dengan MSE terkecil dan waktu komputasi yang cepat. Untuk menentukan jumlah neuron pada hidden layer, pengamatan dilakukan terhadap jaringan dengan satu hidden layer, dengan variasi jumlah neuron hidden layer adalah $10,20,30,40,50,60,70,80,90,100,110$ dan 120 neuron.

- Pelatihan 2, Mencari Momentum dan Laju pembelajaran Terbaik. Pada langkah ini akan diamati variasi momentum dan laju pembelajaran terhadap unjuk kerja jaringan yang dinyatakan dengan besar kecilnya MSE selama proses pelatihan dan lamanya waktu iterasi. Tujuan dari langkah ini adalah untuk memperoleh nilai momentum dan laju pembelajaran yang optimum.

Berikut tahap Identifikasi yaitu:

1. Pengujian terhadap data uji yang dilatih

2. Pengujian terhadap data uji yang tidak dilatih untuk tanpa noise, SNR $20 \mathrm{~dB}$ sampai $80 \mathrm{~dB}$

3. Pengujian dengan data uji respon lain yang tidak dilatih untuk tanpa noise, SNR $20 \mathrm{~dB}$ sampai $80 \mathrm{~dB}$

4. Hasil pengujian dapat diketahui dengan membulatkan nilai output jaringan terlebih dahulu, pada proses ini sistem berfungsi sebagai klasifikasi dari data yang dijadikan input.

\section{HASIL DAN PEMBAHASAN}

Perekaman dilakukan terhadap penutur dengan durasi waktu rata-rata 5 detik pada sampling rate (Fs) sebesar $16000 \mathrm{~Hz}$, mono channels, dan resolution 16-bit. Dalam penelitian ini digunakan 23 penutur yang akan dibagi menjadi 18 orang sebagai penutur didalam database dan 5 orang sebagai penutur diluar database. Penutur didalam database terdiri dari 18 orang laki-laki yang mengucapkan kata "Laboratorium Telkom". Penutur diluar database terdiri dari 3 orang laki-laki dan 2 orang perempuan mengucapkan kata "Laboratorium Telkom". Setiap data ucapan disimpan sebagai sebuah file audio dengan format .wav yang diberi nama sesuai dengan nama penutur, kondisi suara dan diikuti dengan indeks urutan pengucapan.
Pengujian terhadap data uji sama dengan data yang dilatih maka didapatkan data hasil pengujian tersebut. Berikut disajikan dalam tabel 4:

Tabel 4 Hasil pengujian dengan data yang dilatih

\begin{tabular}{|c|c|}
\hline Nama Penutur & Tingkat pengenalan (\%) \\
\hline Ahmadi & $100 \%$ \\
\hline Ahsan & $100 \%$ \\
\hline Alfan & $100 \%$ \\
\hline Arif & $100 \%$ \\
\hline Arifin & $100 \%$ \\
\hline Asgar & $100 \%$ \\
\hline Bahar & $100 \%$ \\
\hline Budi & $100 \%$ \\
\hline Dika & $100 \%$ \\
\hline Ghalib & $100 \%$ \\
\hline Ihlas & $100 \%$ \\
\hline Izi & $100 \%$ \\
\hline Jumadi & $100 \%$ \\
\hline Panji & $100 \%$ \\
\hline Ryan & $100 \%$ \\
\hline Sadik & $100 \%$ \\
\hline Udin & $100 \%$ \\
\hline Zain & $100 \%$ \\
\hline Rata-rata & $\mathbf{1 0 0 \%}$ \\
\hline & \\
\hline &
\end{tabular}

Berdasarkan hasil Tabel 4 dapat disimpulkan bahwa pengujian yang dilakukan dengan data yang sama dengan data yang dilatih dapat dikenali dengan baik oleh sistem dan menghasilkan persentase pengenalan sebesar $100 \%$.

Proses pengujian dilakukan dengan menggunakan data dari setiap penutur dengan mengucapkan kata "Laboratorium Telkom" yang dihasilkan dari setiap perekaman. Dalam sistem ini telah disediakan setiap penutur terdapat 3 suara yang akan dilatih, suara tersebut terdiri dari suara 1 sampai suara 3 . Total data yang dilatih terdapat ada 39 data suara. Pengujian yang dilakukan dengan menguji data yang sama dengan data yang dilatih.

Berikut Pengujian dengan data uji didalam database tanpa noise dapat disajikan dalam tabel 5:

Berdasarkan hasil Tabel 5 dapat disimpulkan bahwa pengujian dengan data uji didalam database tanpa Noise bahwa beberapa data menunjukan kesalahan identifikasi. Hal tersebut disebabkan oleh input dari hasil ekstraksi pada penutur tersebut belum pernah dipelajari (melakukan pelatihan) sehingga sistem tidak dapat mengenali penutur tersebut. Untuk persentase tingkat keberhasilan yang diperoleh adalah sebesar $86 \%$. Pengujian 
dengan data uji didalam database tanpa noise merupakan pengujian dengan menggunakan data ucapan dari suara 4 sampai suara 13. Total data sebagai data uji ada 180 suara. Dimana data hasil proses ekstraksi dengan metode MFCC sebelumnya yaitu suara 1 hingga 3 telah dilakukan pengujian dengan proses pembelajaran terlebih dahulu.

Untuk melihat perilaku dari model JST yang dibangun terhadap data yang diberi SNR, dilakukan pengujian model JST dengan arsitektur yang sama dengan data tanpa noise. Hasil pengujian model JST dengan SNR $20 \mathrm{~dB}$, SNR $30 \mathrm{~dB}$, SNR $40 \mathrm{~dB}$, SNR 50 $\mathrm{dB}$, SNR $60 \mathrm{~dB}$, SNR $70 \mathrm{~dB}$ dan SNR $80 \mathrm{~dB}$.

Tabel 5 Hasil pengujian dengan data uji yang tidak dilatih tanpa Noise

\begin{tabular}{|c|c|}
\hline Nama Penutur & Tingkat pengenalan (\%) \\
\hline Ahmadi & $100 \%$ \\
\hline Ahsan & $100 \%$ \\
\hline Alfan & $100 \%$ \\
\hline Arif & $70 \%$ \\
\hline Arifin & $70 \%$ \\
\hline Asgar & $80 \%$ \\
\hline Bahar & $80 \%$ \\
\hline Budi & $90 \%$ \\
\hline Dika & $100 \%$ \\
\hline Ghalib & $80 \%$ \\
\hline Ihlas & $90 \%$ \\
\hline Izi & $90 \%$ \\
\hline Jumadi & $100 \%$ \\
\hline Panji & $90 \%$ \\
\hline Ryan & $90 \%$ \\
\hline Sadik & $80 \%$ \\
\hline Udin & $70 \%$ \\
\hline Zain & $60 \%$ \\
\hline Rata-rata & $86 \%$ \\
\hline & \\
\hline & \\
\hline
\end{tabular}

Berdasarkan hasil Tabel 6 dapat disimpulkan bahwa pengujian data uji yang tidak dilatih dengan SNR pengenalannya tidak sebaik dari hasil pengujian dengan data uji didalam database tanpa Noise, hal ini dikarenakan suara yg diuji terdapat noise sehingga setiap hasil perbandingan antara data uji tanpa Noise dan data uji dengan noise yg bernilai tidak sama dengan hasil keluaran pengujian pada JST backpropagation tidak dikenali. Untuk tingkat pengenalan masing-masing data uji dengan SNR $20 \mathrm{~dB}$ sebesar $45 \%$, data uji dengan SNR $30 \mathrm{~dB}$ sebesar $52 \%$, data uji dengan

SNR $40 \mathrm{~dB}$ sebesar $72 \%$, data uji dengan SNR $50 \mathrm{~dB}$ sebesar $76 \%$, data uji dengan SNR $60 \mathrm{~dB}$ sebesar $79 \%$, data uji dengan SNR $70 \mathrm{~dB}$ sebesar $82 \%$, dan data uji dengan SNR $80 \mathrm{~dB}$ sebesar 92\%.Selanjutnya, untuk melihat pengaruh data uji yang tidak dilatih tanpa Noise dan data uji yang tidak dilatih dengan SNR tertentu terhadap persentase pengenalan, dilakukan perbandingan persentase pengenalan yang dihasilkan dari Tabel 5 sampai Tabel 6 diatas kemudian dibuat grafik perbandingannya gambar 10:

Dari grafik pada Gambar 10 dapat dijelaskan bahwa semakin besar nilai SNR yang diberikan pada sampel suara maka tingkat pengenalan suara oleh JST akan semakin meningkat. Bila dibandingkan antara pengenalan suara tanpa noise dengan SNR.

Pengujian dengan data uji diluar database merupakan pengujian dengan menggunakan data ucapan dari orang lain. Dalam sistem ini telah disediakan 5 penutur dimana setiap penutur terdiri dari 3 orang laki-laki dan 2 orang perempuan yang mengucapkan kata "Laboratorium Telkom" diulangi sebanyak 5 kali.

Sama seperti pengujian dengan data uji didalam database, Pengujian dengan data diluar database juga tidak dilakukan proses pembelajaran (tahap pelatihan). Disini akan dilihat keandalan sistem dalam menolak atau

Tabel 6 Hasil pengujian dengan data uji dalam database dengan SNR

\begin{tabular}{|c|c|c|c|c|c|c|c|}
\hline \multirow{2}{*}{$\begin{array}{c}\text { Nama } \\
\text { Penutur }\end{array}$} & \multicolumn{7}{|c|}{ Tingkat Pengenalan (\%) } \\
\cline { 2 - 8 } & $\mathbf{2 0}$ & $\mathbf{3 0}$ & $\mathbf{4 0}$ & $\mathbf{5 0}$ & $\mathbf{6 0}$ & $\mathbf{7 0}$ & $\mathbf{8 0}$ \\
\hline Ahmadi & 20 & 30 & 50 & 60 & 50 & 70 & 70 \\
\hline Ahsan & 30 & 40 & 40 & 80 & 90 & 90 & 100 \\
\hline Alfan & 50 & 50 & 70 & 100 & 90 & 100 & 100 \\
\hline Arif & 40 & 60 & 70 & 70 & 70 & 70 & 100 \\
\hline Arifin & 40 & 50 & 70 & 70 & 70 & 70 & 100 \\
\hline Asgar & 30 & 40 & 80 & 80 & 80 & 80 & 90 \\
\hline Bahar & 50 & 60 & 80 & 70 & 60 & 80 & 80 \\
\hline Budi & 60 & 30 & 90 & 70 & 90 & 90 & 90 \\
\hline Dika & 50 & 40 & 100 & 100 & 100 & 100 & 100 \\
\hline Ghalib & 60 & 70 & 70 & 70 & 70 & 80 & 80 \\
\hline Ihlas & 50 & 70 & 50 & 80 & 90 & 90 & 90 \\
\hline Izi & 40 & 50 & 80 & 70 & 90 & 80 & 90 \\
\hline Jumadi & 50 & 60 & 100 & 90 & 100 & 100 & 100 \\
\hline Panji & 50 & 60 & 70 & 80 & 80 & 80 & 90 \\
\hline Ryan & 40 & 70 & 70 & 70 & 80 & 90 & 90 \\
\hline Sadik & 40 & 50 & 80 & 70 & 80 & 80 & 100 \\
\hline Udin & 60 & 50 & 70 & 70 & 70 & 70 & 90 \\
\hline Zain & 50 & 60 & 60 & 6 & 60 & 60 & 90 \\
\hline Rata- \\
rata & $\mathbf{4 5}$ & $\mathbf{5 2}$ & $\mathbf{7 2}$ & $\mathbf{7 6}$ & $\mathbf{7 9}$ & $\mathbf{8 2}$ & $\mathbf{9 2}$ \\
\hline
\end{tabular}




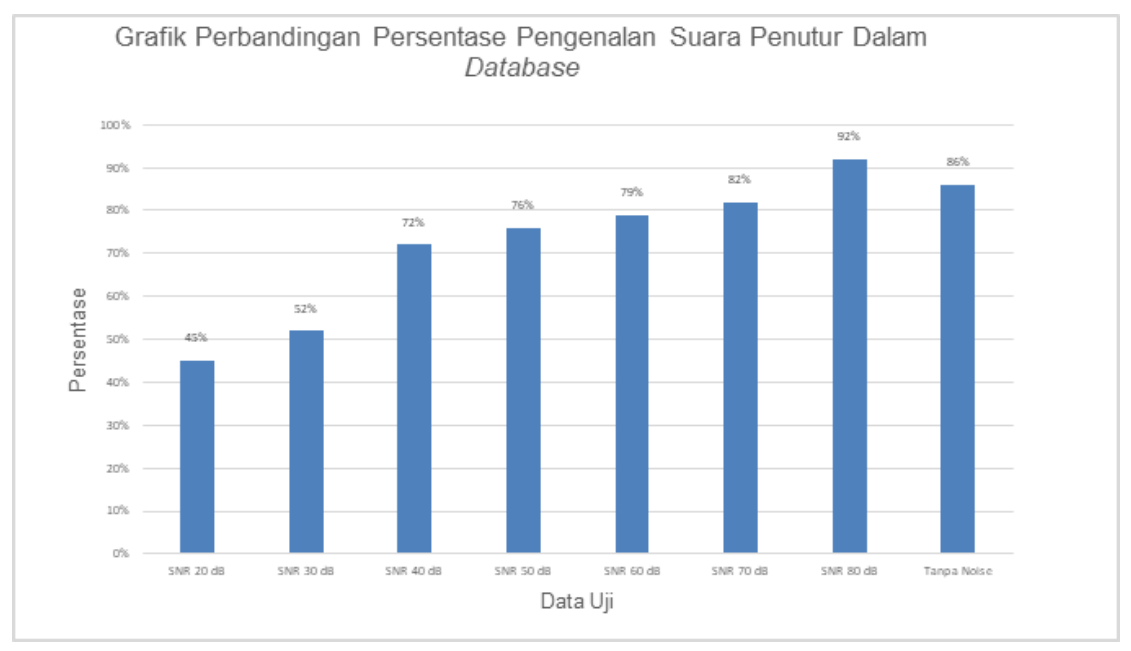

Gambar 10. Grafik Perbandingan persentase pengenalan suara penutur diluar Database

menyatakan tidak mengenal penutur yang tidak dilatih. Berikut disajikan dalam tabel 10

Tabel 10 Hasil pengujian dengan data uji respon lain yang tidak dilatih

\begin{tabular}{|c|c|}
\hline Nama Penutur & Tingkat Penolakan (\%) \\
\hline Ita & $100 \%$ \\
\hline Kahfi & $100 \%$ \\
\hline Nizam & $100 \%$ \\
\hline Rini & $100 \%$ \\
\hline Rully & $100 \%$ \\
\hline Rata-rata & $\mathbf{1 0 0} \%$ \\
\hline
\end{tabular}

\section{KESIMPULAN}

Berdasarkan hasil uji coba dan analisis yang telah dilakukan, maka dapat diambil beberapa kesimpulan antara lain sebagai berikut:

1. Persentase pengenalan untuk penutur sebagai data latih sebesar $100 \%$. Pengujian dengan data uji dalam database tanpa noise memiliki tingkat keberhasilan $86 \%$, untuk data uji dengan SNR $20 \mathrm{~dB}$ memiliki tingkat keberhasilan $45 \%$, untuk data uji dengan SNR $30 \mathrm{~dB}$ memiliki tingkat keberhasilan $52 \%$, untuk data uji dengan SNR $40 \mathrm{~dB}$ memiliki tingkat keberhasilan $72 \%$, untuk data uji dengan SNR $50 \mathrm{~dB}$ memiliki tingkat keberhasilan $76 \%$, untuk data uji dengan SNR $60 \mathrm{~dB}$ memiliki tingkat keberhasilan $79 \%$, untuk data uji dengan SNR $70 \mathrm{~dB}$ memiliki tingkat keberhasilan $82 \%$, untuk data uji dengan SNR $80 \mathrm{~dB}$ memiliki tingkat keberhasilan $92 \%$.
2. Pengujian dengan data uji diluar database memiliki tingkat penolakan $100 \%$

3. Dari hasil pengujian didapatkan bahwa dengan tingkat SNR yang tinggi persentase tingkat pengenalan akan meningkat.

\section{DAFTAR PUSTAKA}

[1] Darma, P., "Verifikasi Biometrika Suara Menggunakan Metode MFCC dan DTW" , Jurusan Teknik Elektro Fakultas Teknik Universitas Udayana, 2011.

[2] Susanto,N., "Pengembangan Metode Jaringan Syaraf Tiruan Resilient Backpropagation untuk Identifikasi Pembicara dengan Praproses MFCC ", Departemen IImu Komputer, Fakultas Matematika Dan IImu Pengetahuan Alam, Institut Pertanian Bogor, 2007.

[3] Kanata, Bulkis,"Bahan Ajar kuliah Jaringan Syaraf Tiruan", Jurusan Teknik Elektro Fakultas Teknik Universitas Mataram 2014.

[4] Purnamasari, R.W., "Implementasi Jaringan Syaraf Tiruan Backpropagation sebagai Sistem Deteksi Penyakit Tuberculosis (TBC)", Jurusan Matematika Fakultas Matematika Dan IImu Pengatahuan Alam Universitas Negeri Semarang, 2013.

[5] Siang, J.J, "Jaringan Syaraf Tiruan dan Pemrograman Menggunakan MATLAB", Yogyakarta: ANDI, 2009. 